\title{
Evaluation of drought regimes and impacts in the Limpopo basin
}

\section{B. F. Alemaw ${ }^{1}$ and J.-M. Kileshye-Onema ${ }^{2}$}

${ }^{1}$ University of Botswana; Department of Geology, Gaborone, Botswana

${ }^{2}$ WaterNet, University of Zimbabwe, Harare, Zimbabwe

Received: 21 September 2013 - Accepted: 28 October 2013 - Published: 7 January 2014

Correspondence to: B. F. Alemaw (alemaw @mopipi.ub.bw)

Published by Copernicus Publications on behalf of the European Geosciences Union.

Evaluation of drought regimes and impacts in the Limpopo basin

B. F. Alemaw and

\section{J.-M. Kileshye-Onema}

Title Page

Abstract

Conclusions

Tables

14

$<$

Back

Full Screen / Esc

Printer-friendly Version

Interactive Discussion 


\section{Abstract}

Drought is a common phenomenon in the Limpopo River basin. In essence, droughts are long-term hydro-meteorological events affecting vast regions and causing significant non-structural damages. In the interest of riparian states' joint integrated water

5 resources development and management of the Limpopo basin, inter regional drought severity and its impacts should be understood. The study focussed on case studies in the basin which is subdivided into four homogeneous regions owing to topographic and climate variations based on the previous work of the same authors. Using the medium range time series of the Standardized Precipitation Index (SPI) as an indicator of ght, for each homogeneous region monthly and annual Severity-Area-Frequency (SAF) curves and maps of probability of drought occurrence were constructed. The results indicated localized severe droughts in higher frequencies, while only moderate to severe low frequency droughts may spread over wider areas in the basin. The regionlevel Drought-Severity Indices can be used as indicators for planning localized interto develop improved drought indicators, to assess the relationship between drought hazard and vulnerability and to enhance the performance of methods currently used for drought forecasting. Results on the meteorological drought linkage with hydrological and vegetation or agricultural drought indices are presented as means of validaregion. In general, this preliminary investigation reveals that the western part of the basin will face a higher risk of drought when compared to other regions of the Limpopo basin in terms of the medium-term drought. The Limpopo basin is water stressed and livelihood challenges remain at large, thus impacts of droughts and related resilience options should be taken into account in the formulation of regional sustainable water resources development strategies. This study is exciting in the manner that the variations in the sub-basin drought severities are revealed and are used to suggest the corresponding drought monitoring and management strategies. This will have an
HESSD

11, 199-222, 2014

Evaluation of drought regimes and impacts in the Limpopo basin

B. F. Alemaw and J.-M. Kileshye-Onema

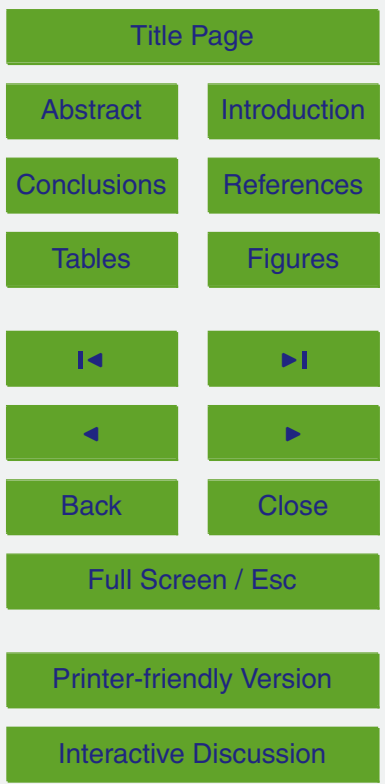


overall effect in developing a basin-wide framework for integrated drought management as well as water resources development and management, which requires cooperative efforts among the riparian countries of the Limpopo basin.

\section{Introduction}

5 Differences in hydrometeorological variables and socioeconomic factors as well as the stochastic nature of water demands in different regions around the world have become an obstacle to having a precise definition of drought (Mishra and Singh, 2010).

There are a number drought classifications provided by the scientific community. Mawdsley et al. (1994) defined two classes or types of indicators, namely the environmental indicators and water resource indicators. According to Mawdsley et al. (1994), environmental indicators are those hydro-meteorological and hydrological indicators, which measure the direct effect on the hydrological cycle. The nature of the water deficit might be related to precipitation, streamflow or soil moisture. These indicators can help in identifying the duration and/or severity of a drought and can be used to analyse the drought frequency. Environmental definitions usually determine the degree of departure from average conditions. On the other hand, water resource indicators measure severity in terms of the impact of the drought on the use of water in its broadest sense, for example, impact on water supply for domestic or agricultural use, impact on groundwater recharge, abstractions and surface water levels, impact on fisheries or impact on recreation among others. This implies that an element of human interference as an increased water demand or mismanagement of water supply, as well as a lack of rainfall or runoff determines the drought.

Other definitions, provided by Wilhite and Glantz (1985) consider drought into conceptual and operational types. The former, conceptual definition refers to definitions
HESSD

$11,199-222,2014$

Evaluation of drought regimes and impacts in the Limpopo basin

B. F. Alemaw and

J.-M. Kileshye-Onema

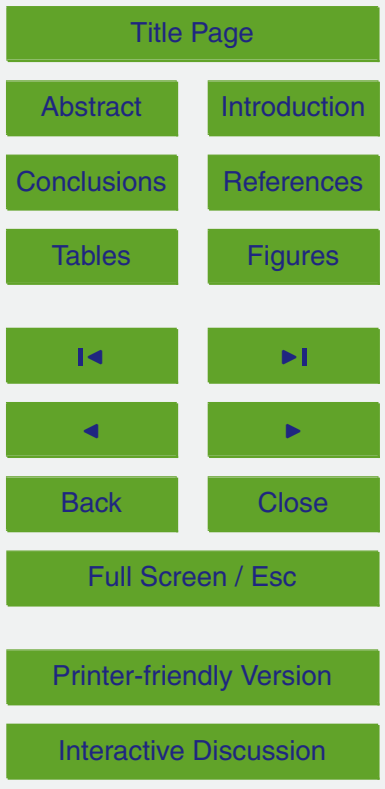
The latter, operational definition encompasses definitions attempting to identify the onset, severity and termination of drought episodes. In some publications (e.g. Tallaksen, 
2000; Tate and Gustard, 2000) the definition of operational drought is applied equivalent to water resource indicators, and therefore not consistent with the broad definition provided by Wilhite and Glantz (1985).

Other classification methods are also available for drought based on a disciplinary 5 perspective such as in Dracup et al. (1980), in which droughts are related to precipitation (meteorological), streamflow (hydrological), soil moisture (agricultural) or any combination of the above three categories. A more elaborate and similar classification can be found in Wilhite and Glantz (1985), where four categories are identified as follows (Hisdal and Tallaksen, 2000):

1. meteorological drought: it is usually an expression of precipitation's departure from normal over some period of time. It is one of the primary causes of a drought. Several studies have analyzed droughts using monthly precipitation data (Mishra and Singh, 2010). Other approaches analyze drought duration and intensity in relation to cumulative precipitation shortages (Estrela et al., 2000; Chang and Kleopa, 1991);

2. hydrological drought: usually expressions of deficiencies in surface and subsurface water supplies. It reflects effects and impacts of droughts;

3. agricultural drought: usually expressed in terms of needed soil moisture of a particular crop at a particular time; and

4. socio-economic drought: definitions associating droughts with supply of and demand for an economic good.

The first three groups could be defined as environmental indicators, the last group as a water resource indicator (Tallaksen, 2000).

Droughts are usually indicated by drought indices, the most commonly-used meteorological drought indices are: (1) rainfall deciles (Palmer, 1965, 1968); (2) the Palmer Drought Severity Index (PDSI) (Ayvaz et al., 2007); and (3) the Standardized Precipitation Index (SPI) (Zhang et al., 2009). In quantification of precipitation deficit for multiple
HESSD

11, 199-222, 2014

Evaluation of drought regimes and impacts

in the Limpopo basin

B. F. Alemaw and

J.-M. Kileshye-Onema
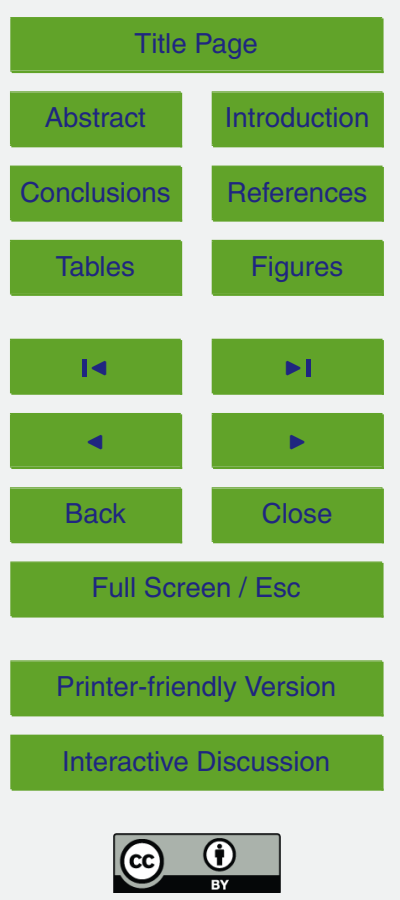
time scales and evaluations of the impact of drought on the availability of water resources, the standardized precipitation index (SPI) was considered as a prior drought index to construct Severity-Area-Frequency (SAF) curves and was also in Alemaw et al. (2013).

5 Droughts are of great importance in the planning and management of water resources especially in the water scare basins such as the Limpopo basin. The objectives of this manuscript are to understand drought regimes and implications of drought to sustainability of agricultural use and crop production under rainfed conditions referring to the Limpopo basin as a case study. Specifically, the manuscript focuses on:

10 (1) drought characterization, drought regionalization from SPI, drought severity indices (DSI) and drought Severity-Area-Frequency (SAF); (2) sustainability analysis of crop resilience using soil-moisture accounting water balance model; and (3) analysis of crop production impacts with ensembles of historical climate.

This study was conducted as part of the EU funded project on Improved Drought 15 Early Warning for Adaptation and Preparedness in Africa (DEWFORA). An overview of results thus far has been documented recently in Werner et al. (2013).

\section{Study area and data}

The Limpopo River basin which falls grossly between $25-35^{\circ} \mathrm{E}$ and $19-27^{\circ} \mathrm{S}$, and it is one of the largest river basin in Southern Africa with average rainfall of $530 \mathrm{~mm}$ per 20 annum and is home to 14 million inhabitants. The Limpopo River basin drainage area is $413000 \mathrm{~km}^{2}$, and drains through four riparian countries: Botswana, Zimbabwe, South Africa and Mozambique.

Precipitation data with monthly time scale of some 94 stations within the region were collected. The common record length of the stations spans from 1950 to early 2010s which is adequate for drought-related study. The FAO CLIMWAT database was used to extract median monthly precipitation data for stations where no national data was available for the study, mainly Zimbabwe and South Africa (Fig. 1).

\section{HESSD}

$11,199-222,2014$

Evaluation of drought regimes and impacts in the Limpopo basin

B. F. Alemaw and J.-M. Kileshye-Onema

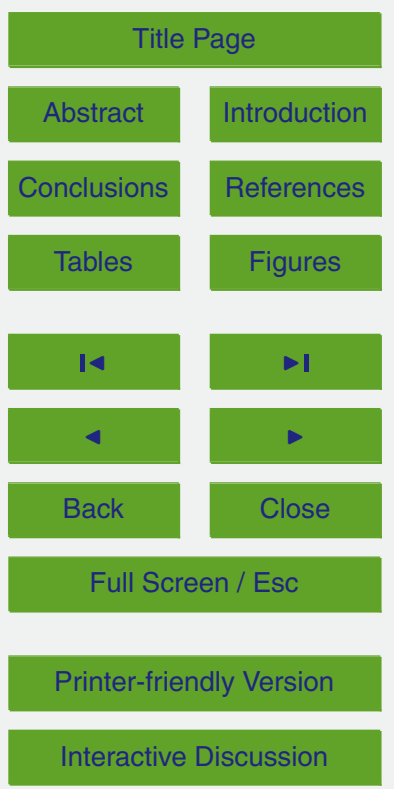


For those stations with monthly time series of precipitation data, the drought duration and SPI were extracted for 1, 3, 6, 9, 12 and 24 month durations to derive drought severity indices.

Simulations of daily and seasonal soil moisture through crop-specific water balance 5 modelling and calculations were also undertaken for selected sites to derive various drought indices to analyse drought and its implications to agriculture as well as rainfed crop sustainability presented through the various cases studies presented in the different sections as follows.

Crop and agronomic data for selected crops were used from Region 3 and daily 10 long-term meteorological variables especially using soil moisture accounting crop speagricultural yield data were collected for typical agricultural districts in Region 3.

The Limpopo basin is also characterised by missing or poorly coordinated and doc15 umented data and information on hydrological infrastructures such as reservoirs (Mulengera et al., 2012) as such this study only considers impacts on hydrological drought where adequate information could be gathered.

\section{Methodology}

\subsection{Drought regions of the Limpopo basin}

20 A spatial analysis of drought characteristics in the Limpopo basin is undertaken to evaluate its regional implications to water management challenges. In this study, drought duration, frequency and severity are investigated. The entire Limpopo River basin is subdivided into different four homogeneous regions owing to topographic and climate variations in the basin which was based on K-Means Clustering algorithm (Alemaw et al., 2013). The Fuzzy C-Means (FCM) clustering, employed for this purpose, is a modification of the K-means algorithm that minimizes intra-cluster variance (Ayvaz
HESSD

$11,199-222,2014$

Evaluation of drought regimes and impacts in the Limpopo basin

B. F. Alemaw and J.-M. Kileshye-Onema

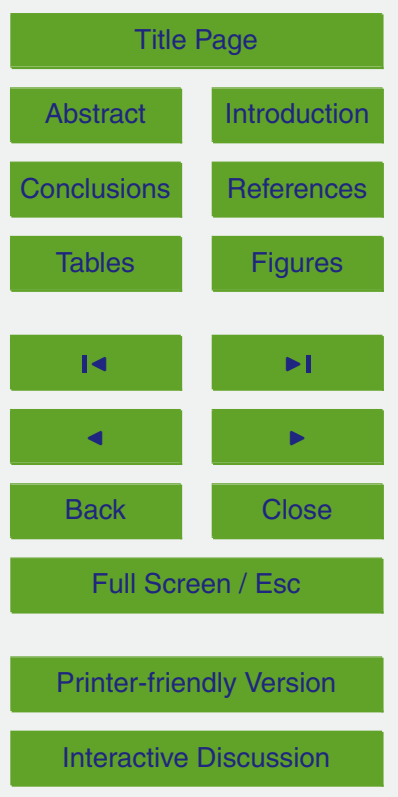


et al., 2007) to include grouping of sites using the clustering algorithm. Factors that affect annual rainfall and seasonal variability considered in the study and used for clustering are: elevation, longitude, latitude and median monthly rainfall.

The algorithm assumes that the attributes are from a vector space and is targeted to 5 achieve a minimized total intra-cluster variance function, $D_{\mathrm{v}}$ is given as (Zhang et al., 2009; Sadri and Burn, 2011):

$D_{\mathrm{v}}=\sum_{k=1}^{N} \sum_{x_{j} \in s_{k}}^{N}\left|x_{j}-c_{k}\right|^{2}$

Where $c_{k}$ is the centroid point of all the points in cluster $k ; N$ the total number of clusters; $S_{k}$ the set of points in the $k$ th cluster; $x_{j}$ the standardized vector for site $j$. 10 The FCM algorithm is initiated with an initial set of $k$ groups and then it calculates the centroid point of each set within a cluster. A detailed account of the process followed is available in (Alemaw et al., 2013).

The same authors also constructed drought Severity-Area-Frequency (SAF) curves for short and medium term SPI indices. Precipitation data of 94 stations in the Limpopo basin were used in determinining the four drought regions cited in the avove literature. The stations used and the drought regions are illustrated in Fig. 1.

The Standardized Precipitation Index (SPI) was developed and widely applied for the purpose of defining and monitoring drought (McKee et al., 1993). The practical application of this index is evident from different users which depend on the SPI to monitor current states of drought amongst them are the European Drought Center, the US Colorado Climate Center, and the US National Drought Mitigation Center. SPI can be used to track drought on multiple time-scales and it the index is flexible with respect to the period chosen. For instance, the US National Drought Mitigation Center computes the SPI with five running time intervals, namely: 1, 3, 6, 9, and 12 months.

The desired intervals can be chosen depending on the purpose of the drought impact study. The use of SPI over the traditional PDSI is advocated by the US National Drought Mitigation Center and the US Western Regional Climate Center (Redmond, 2000).
HESSD

11, 199-222, 2014

Evaluation of drought regimes and impacts in the Limpopo basin

B. F. Alemaw and

J.-M. Kileshye-Onema

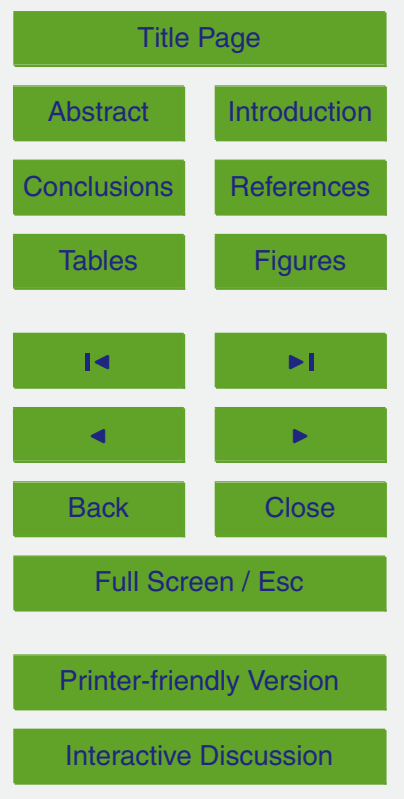


For each region, Drought Severity Indices were obtained from drought intensity and duration considering the SPI. In the study reported in Alemaw et al. (2013), the theory of runs (Yevjevich, 1967) was adopted to determine properties of droughts. Based on the classification of drought, the truncation level was held as -0.99 in this runs analysis.

5 A hydrologic drought event is considered as an event during which SPI is continuously below the truncation level. Drought duration is the period of time when SPI is continuously below the truncation level and drought severity is the cumulative deficit below the truncation level for the duration of a drought event. Drought categories were set from calculated Standardized Precipitation Index (SPI) based on the criteria shown in

10 Table 1. Computation of the SPI involves fitting a Gamma probability density function to a given frequency distribution of precipitation totals for a station. The parameters of the Gamma probability density function are estimated for each station, for each time scale of interest (1, 3, 6, 9, 12 months, etc.), and for each month of the year. This procedure is widely used and illustrated in Loukas and Vasiliades (2004).

\subsection{Drought and its impact on sustainability and resilience of crop production}

Major drought and its impacts can be manifested in the way it affects soil moisture and crop production in general. The primary impact in the sustainability of rainfed systems is understood through simulation of daily and seasonal simulations and soil moisture 20 modelling coupled with risk analysis of various crops under rainfed systems. A recent account of how risk, resilience, vulnerability indices are used and the concepts applied is presented in a case study site within Limpopo (Region 3), as presented in Alemaw (2012).

There is clear evidence showing that soil fertility constraints often constitute the pri25 mary limiting factor to crop growth in drylands (Klaij and Vachaud, 1992). Drought impact can be assessed using crop- soil-water simulations of longterm meteorological variables especially using soil moisture accounting crop specific (SMACS) model (Alemaw et al., 2006). More recent studies focussed on the assessment of availability

\section{HESSD}

$11,199-222,2014$

Evaluation of drought regimes and impacts in the Limpopo basin

B. F. Alemaw and J.-M. Kileshye-Onema

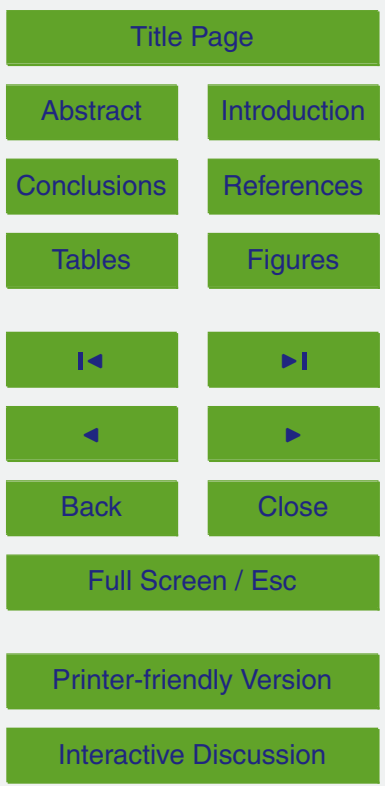


of soil moisture, which is an integrating variable for the underlying hydroclimatic and agronomic factors of rainfed agricultural areas (Alemaw, 2012; Hlavinka, et al., 2011; Jones et al., 2003). The risk level for sustenance of rainfed systems can be determined as a probability at which soil moisture $(S)$ drops below a given moisture threshold 5 (SWP $+\mathrm{d} t)$ during the crop's length of the growing period (LGP). The risk factor, $r$, for the entire growing period (simulation period) of crops under rainfed conditions can be calculated as defined in Alemaw (2012):

$r[\%]=\frac{n}{T} \times 100 \%$

Where $n$ is the number of days in which actual soil moisture $S$, drops below the critical soil moisture threshold (SWP $+\mathrm{d} t$ ) during the total number of days $(T)$ of the entire cropping period. In a period of years of analysis considered, $T$ in days becomes the product of the number of the simulated years and the length of the growing period (LGP) in days.

The risk factor here is the same as the probability of failure which refers to the proportion of days to the total number of days or the length of the growing period (LGP), within which the simulated soil moisture drops below the amount which is set at $p$ times the readily available soil moisture content $\left(S_{\mathrm{FC}}-S_{\mathrm{WP}}\right)$, where the subscripts FC and WP for the moisture content $S$ represent the field capacity and wilting point, respectively. If other agricultural conditions such as land management and nutrient availability are not altered, then this risk factor integrates the prevailing hydroclimatology, soil moisture availability and crop-soil-water conditions, to assess sustainability of various crops under rainfed conditions.

For assessment of soil moisture reliability and sustainability of rainfed systems, we recommend a set of indices that are used as quantitative measures, details of which 25 are presented in Alemaw (2012). The indices measure reliability, risk of failure and resilience for classifying and assessing the sustainability of rainfed agricultural systems. Reliability is a measure of frequency or probability that a system is in a satisfactory state meeting a given criterion. Resiliency generally indicates a measure of how quickly 207

\section{HESSD}

$11,199-222,2014$

Evaluation of drought regimes and impacts in the Limpopo basin

B. F. Alemaw and J.-M. Kileshye-Onema

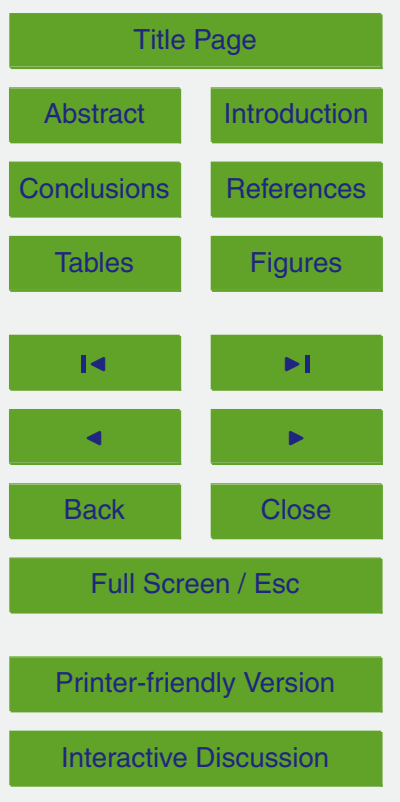


a system recovers from shocks or failures when these have occurred. The computational scheme for these indices in this study is almost similar to that of Hashimoto et al. (1982), Maier et al. (2001), and Fowler et al. (2003), specifically tailored for analyzing risks and sustainability of rainfed systems in addition to the fact that a different 5 criterion was set.

Defining a criterion $(C)$ as the minimum required soil moisture from a rainfed agricultural system, the daily soil moisture depth $\left(d_{t}\right)$ can be classified as a satisfactory state $(A)$ or a failure state $(B)$, i.e.,

$S_{t} \geq C\left\{\begin{array}{l}\text { then } d_{t} \in A \text { and } Z_{t}=1 \\ \text { else } d_{t} \in B \text { and } Z_{t}=0\end{array}\right.$

Where $Z_{t}$ is a generic indicator variable. The daily available moisture content simulated in the Soil Moisture Accounting Crop Specific (SMACS) model (Alemaw et al., 2006) was used as a criterion and, thus, system failure occurs when soil moisture is below the criterion at any given day. The criteria can be moisture depth $d_{t}$ being below $15 p\left(S_{\mathrm{FC}}-S_{\mathrm{WP}}\right)$, where $p$ is chosen soil moisture factor such as $0-30 \%$ which is a limiting moisture factor in relation to the soil water holding capacity of the soil (WHC) or available soil moisture content $\left(\mathrm{WHC}=S_{\mathrm{FC}}-S_{\mathrm{WP}}\right)$ of the soil.

\subsection{Assessment of agricultural drought}

Agricultural drought, besides the challenges of soil moisture impacts can be explained

in terms of sustainability of rainfed crop production systems and crop productivity. One needs to undertake detailed investigations of agricultural droughts to understand crop production systems - based on agricultural statistical data analysis as well as cereal yields. Other important aspects include: livestock production systems; state of cattle feed supply; biomass and grazing land availability; animal feeding balance; and imports

The most obvious agricultural impact of drought can be studied using the water requirement satisfaction index (WRSI) which is relatively a relevant index to monitor

HESSD

$11,199-222,2014$

Evaluation of drought regimes and impacts in the Limpopo basin

B. F. Alemaw and J.-M. Kileshye-Onema

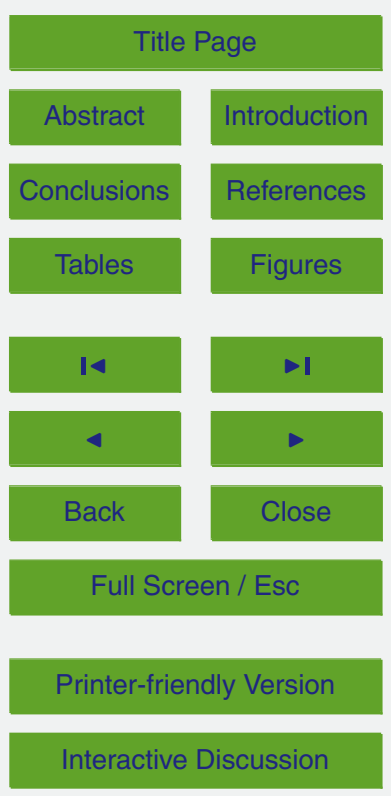


agricultural drought. WRSI is an indicator of crop performance based on the availability of water to the crop during a growing season. The WRSI was generated by a crop water balance model, SMACS model. SMACS stands for Soil moisture accounting crop specific model as documented and further elaborated in Alemaw et al. (2006). It was 5 applied using the following criteria.

Within the SMACS model, WRSI was calculated as the ratio of seasonal actual evapotranspiration (ETa) to the seasonal crop water requirement (WR) i.e.

WRSI $=(E T a / W R) 100$

In which WR is reference crop evapotranspiration (ETo) calculated from the PenmanMonteith model using the crop coefficient $(\mathrm{Kc})$ to adjust for the growth stage of the crop, $\mathrm{WR}=\mathrm{ETO} \cdot \mathrm{KC}$. Whereas, ETa represents the actual amount of water withdrawn from the soil water reservoir where shortfall relative to potential or reference evapotranspiration (ETo) is calculated by function that takes into account the amount of soil water in the reservoir. Soil water content was estimated through simple mass balance equation

\section{Results and discussions}

\subsection{Drought regions of the Limpopo basin}

Drought characteristics for each of the four regions illustrated in Fig. 1 are studied based on the Severity-Area-Frequency curves for each homogeneous region (Alemaw et al., 2013). The regional distribution in terms of the mean of the regional drought severity is illustrated in Fig. 3. As illustrated, the droughts corresponding to the short-, medium- and long-term periods are of great importance for devising different water resource management strategies in the different regions. In this case, the SeverityArea-Frequency analysis for each homogeneous region corresponding to the short-,

Evaluation of drought regimes and impacts in the Limpopo basin

B. F. Alemaw and J.-M. Kileshye-Onema

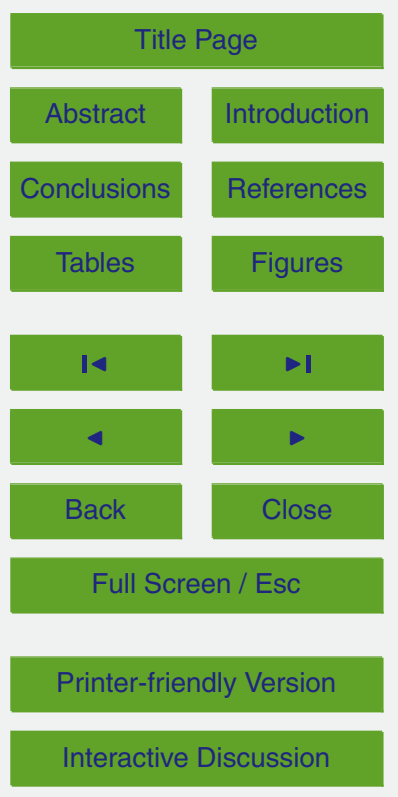

Interactive Discussion 
medium- and long-term drought show that when there occurs a severe drought, the drought events may have impacts on the entire Limpopo River basin.

A typical drought severity index (DSI) and its areal extent (Severity-Area-Frequency, SAF) of Region 3 is presented in Fig. 2. Figure 2 shows the 2, 5, 10, 20, 50 and

$5100 \mathrm{yr}$ return period or drought frequencies based on SPI-3 (three-month SPI). The corresponding DSIs for typical drought years of 1986/87 and 1994/95 are also shown. These periods represent a moderate and severe drought periods, respectively. The drought of 1986/87 has a return period of approximately $15 \mathrm{yr}$ (falling in the range of 10 to $20 \mathrm{yr}$ ). On the other hand, drought of the 1994/95 appears to a have a drought 10 frequency of approximately $30 \mathrm{yr}$ (between 20 and $50 \mathrm{yr}$ ). The results also indicated localized severe droughts in higher frequencies, while only moderate to severe low frequency droughts spreading over wider areas in this region, which represent one of the most drought-prone part of the Limpopo basin. This can be seen from the basin wide summary of drought severity indices presented in Fig. 3 that illustrate droughts of short and longtern time scales of SPIs of 1, 3, 6, 9, 12 and 24 months.

\subsection{Meteorological drought impact on sustainability and resilience of crop pro- duction}

Daily simulations from climatic data of 1961-2001 were made for two districts in Region 3 of the Limpopo basin, considering commonly grown crops: maize, sunflower, and sorghum. For the same crop generally Bobonong District displayed slightly higher risk, lower reliability and higher resilience compared to Palapye. Risk, reliability and resilience of maize simulated from the entire 1961-2000 daily record and taking the actual cropping length, at available soil moisture factor, $p=10 \%$ for Palapye District and Bobonong Districts, two regions located in drought Region 3, is shown in Fig. 4. It can be noted that there is no marked difference in the drought sensitivity of maize in both the districts which is regularly affected by drought and more or less similar drought severity exposure spreading in the this particular region. In this region, other crops considered, sunflower, and sorghum, have different degrees of drought sensitivity as

Evaluation of drought regimes and impacts in the Limpopo basin

B. F. Alemaw and J.-M. Kileshye-Onema

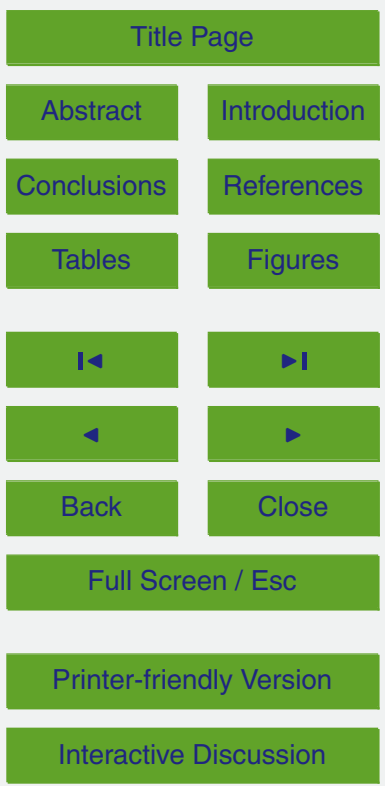


presented in Alemaw (2012). Similarly, the study cab be extended to the other drought regions of the Limpopo basin in order to quantify the extent of drought impact and sensitivity of crops in the different agroecological settings of the basin.

\subsection{Assessment of agricultural drought in the Limpopo basin}

5 The impact of agricultural drought on crop production can be largely expressed by yield reduction. For this, yield reduction due to water deficiency was computed within SMACS model software. Yield reduction was calculated from water balance output combined with an empirical formula developed by Doorenbos and Kassam (1979), Gardner et al. (1981), and Hsiao (1973):

${ }_{10} \mathrm{Yr}=100-((1-(1-A / B) \mathrm{Ky}) 100)$

in which $A$ is the actual evapotranspiration, $B$ is the total water requirement without water stress, and Ky is a crop dependent stress indicator.

The agricultural statistics database mainly for Region 3 was also used to analyse the implications of drought to crop yield. Figure 5 shows a variation of national crop production and its yield. It can be clearly evident how the droughts of 1986-1987, 1994-1995 and 1999-2000 have affected agricultural yield. It can also be noted that the consequence of a particular drought year will have a pronounced effect in that year's or later year's yield.

From Fig. 5, especially in Region 3, it can be noted that there have been decline 20 in both annual grain production as well as their productivity per hectare at more or less in cycles and intervals of five to ten years. The impact of the drought on declining agricultural production in this region especially the drought impacts of the 1985-1986 and 1994-1995 can also be traced back to the wider regional impact of drought as depicted in the DSI and SAF plot shown in Fig. 2.

\section{HESSD}

11, 199-222, 2014

Evaluation of drought regimes and impacts

in the Limpopo basin

B. F. Alemaw and

J.-M. Kileshye-Onema

Title Page

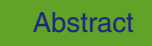

Introduction

Conclusions

Tables

References

Figures

14

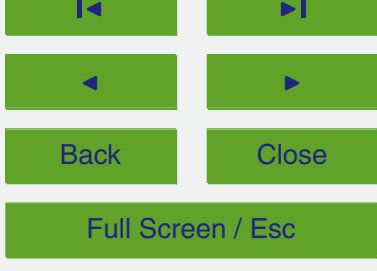

Printer-friendly Version

Interactive Discussion 


\section{Conclusions}

The study focussed on drought-related case studies in the Limpopo basin. First, it was established that the basin is subdivided into four homogeneous regions owing to topographic and climate variations based on the previous work of the same authors. Using 5 the medium range time series of the Standardized Precipitation Index (SPI) as an indicator of drought, for each homogeneous region we produced monthly and annual Severity-Area-Frequency (SAF) curves and maps of probability of drought occurrence. The results indicated localized severe droughts in higher frequencies while only moderate to severe low frequency droughts may spread over wider areas in the basin.

At regional level, the drought severity for each homogeneous region corresponding to the short-, medium- and long-term drought are presented and marked differences in drought severity is evident for the various regions. The region-level Drought-Severity Indices were further used as indicators for assessing drought impacts in the region.

In a detailed analysis of soil moisture availability and rainfed production systems were also used as proxy indicators of drought impacts in the basin by focussing on each homogeneous region. It is evident that droughts and their severity investigated from SPI analysis were also having a link to agricultural production declines. In general, this preliminary investigation reveals that the western part of the basin will face a higher risk of drought when compared to other regions of the Limpopo basin in terms of the medium-term drought. The Limpopo basin is water stressed and livelihood challenges remain at large, thus impacts of droughts and related resilience options should be taken into account in the formulation of regional sustainable water resources development strategies.

Acknowledgements. The authors and WaterNet thank the EU 7th Framework Programme Collaborative Research Project, Improved Drought Early Warning and FORecasting to strengthen preparedness and adaptation to droughts in Africa (DEWFORA) for supporting the research project. The authors also acknowledge the synonymous reviewers of this paper.
HESSD

11, 199-222, 2014

Evaluation of drought regimes and impacts in the Limpopo basin

B. F. Alemaw and J.-M. Kileshye-Onema

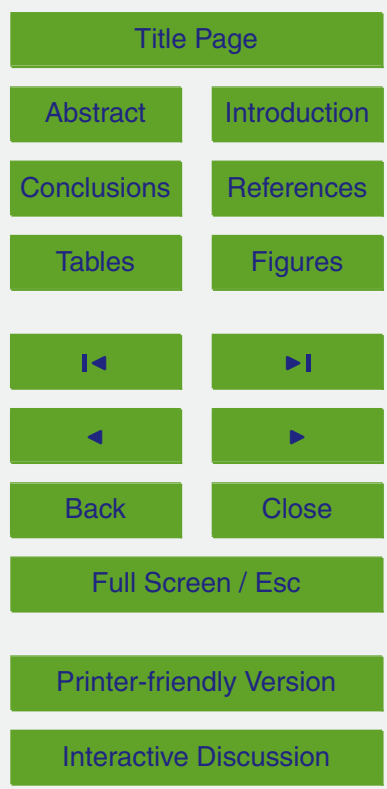




\section{References}

Alemaw, B. F.: Resilience, reliability and risk analyses of maize, sorghum and sunflower in rain-fed systems using a soil moisture modeling approach, Agr. Sci., 3, 114-123, 2012.

Alemaw, B. F., Chaoka, T. R., and Totolo, O.: Investigation of sustainability of rain-fed agricul5 ture through soil moisture modeling in the Pandamatenga Plains of Botswana, Phys. Chem. Earth, 31, 960-966, 2006.

Alemaw, B. F., Kileshye-Onema, J. M., and Love, D.: Regional drought severity assessment at a basin scale in the Limpopo Drainage System, J. Water Resour. Protec., accepted, 2013.

Ayvaz, M. T., Karahan, H., and Aral, M. M.: Aquifer parameter and zone structure estimation using kernel-based Fuzzy c-Means clustering and genetic algorithm, J. Hydrol., 343, 240253, 2007.

Chang, T. J. and Kleopa, X.: A proposed method for drought monitoring, Water Res. Bull., 27, 275-281, 1991.

Doorenbos, J. and Kassam, A. H.: Yield Response to Water, FAO Irrigation Drainage Paper, 33, Rome, Italy, 193 pp., 1979.

Doorenbos, J. and Pruitt, W. O.: Guidelines for Predicting Crop Water Requirements, FAO Irrigation and Drainage Paper, No. 24, Rome, Italy, 1979.

Dracup, J. A., Lee, K. S., and Paulson Jr., E. G.: On the definition of droughts, Water Resour. Res., 16, 297-302, 1980.

20 Estrela, M. J., Peñarrocha, D., and Millán, M.: Multi-annual drought episodes in the Mediterranean (Valencia Region) from 1950-1996, a spatio-temporal analysis, Int. J. Climatol., 20, 1599-1618, 2000.

Fowler, H. J., Kilsby, C. G., and O'Connell, P. E.: Modeling the impacts of climatic change and variability on the reliability, resilience, and vulnerability of a water resource system, Water Resour. Res., 39, 1222, doi:10.1029/2002WR001778, 2003.

Gardner, B. R., Blad, B. L., Gassity, D. P., and Watts, D. G.: Relationship between crop temperature, grain yield, evapotranspiration and phenological development in two hybrids of moisture stressed sorghum, Irrig. Sci., 2, 213-224, 1981.

Hashimoto, T., Stedinger, J. R., and Loucks, D. P.: Reliability, resiliency, and vulnerability criteria for water resource system performance evaluation, Water Resour. Res., 18, 14-20, 1982.
HESSD

11, 199-222, 2014

Evaluation of drought regimes and impacts

in the Limpopo basin

B. F. Alemaw and

J.-M. Kileshye-Onema

Title Page

Abstract

Introduction

Conclusions

Tables

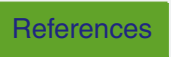

Figures

14

$\rightarrow$

4

Back

Close

Full Screen / Esc

Printer-friendly Version

Interactive Discussion 
Hisdal, H. and Tallaksen, L. M.: Drought event definition, in: Assessment of the Regional Impact of Droughts in Europe (ARIDE), edited by: Hisdal, H. and Tallaksen, L. M., ARIDE Report No. 6, chap. 2: Classification, 3-5, University of Oslo, Oslo, Norway, 2000.

Hlavinka, P., Trnka, M., Balek, J., Semerádová, D., Hayes, M., Svoboda, M., Eitzinger, J., Možný, M., Fischer, M., Hunt, E., and Žalud, Z.: Development and evaluation of the SoilClim model for water balance and soil climate estimates, Agr. Water Manag., 98, 1249-1261, 2011.

Hsiao, T. C.: Plant responses to water stress, Ann. Rev. Plant Physio., 24, 519-570, 1973.

Jones, J. W., Hoogenboom, G., Porter, C. H., Boote, K. J., Batchelor, W. D., Hunt, L. A., Wilkens, P. W., Singh, U., Gijsman, A. J., and Ritchie, J. T.: The DSSAT cropping system model, Eur. J. Agron., 18, 235-265, 2003.

Klaij, M. C. and Vachaud, G.: Seasonal water balance of a sandy soil in Niger cropped with pearl millet, based on profile moisture measurements, Agr. Water Manag., 21, 313-330, 1992.

Loukas, A. and Vasiliades, L.: Probabilistic analysis of drought spatiotemporal characteristics 15 inThessaly region, Greece, Nat. Hazards Earth Syst. Sci., 4, 719-731, doi:10.5194/nhess4-719-2004, 2004.

Maier, H. R., Lence, B. J., Tolson, B. A., and Foschi, R. O.: First-order reliability method for estimating reliability, vulnerability, and resilience, Water Resour. Res., 37, 779-790, 2001.

Mawdsley, J., Petts, G., and Walker, S.: Assessment of drought severity, British Hydrological Society Occasional Paper No. 3, Wallingford, UK, 1994.

McKee, T. B., Doesken, N. J., and Kleist, J.: The relationship of drought frequency and duration to time scales, Preprints of the 8th Conference on applied Climatology, Anaheim, California, 179-184, 17-22 January, 1993.

Mishra, A. K. and Singh, V. P.: A review of drought concepts, J. Hydrol., 391, 202-216, 2010.

Mulengera, P.-M. B., Manzungu, E., Kileshye Onema, J.-M.: ICT-based identification and characterisation of small reservoirs in the Limpopo river basin in Zimbabwe, Env. Nat. Resourc. Res., 2, 1927-0496, 2012.

Palmer, W. C.: Meteorological drought, Research Paper No. 45, US Weather Bureau, Washington DC, USA, 1965.

30 Palmer, W. C.: Keeping track of crop moisture conditions, nationwide: the new crop moisture index, Weatherwise, 21, 156-161, 1968.

Redmond, K. T.: Integrated climate monitoring for drought detection, in: Drought: a Global Assessment, edited by: Wilhite, D. A., Routledge, 145-158, London, UK, 2000.

\section{HESSD}

11, 199-222, 2014

Evaluation of drought regimes and impacts

in the Limpopo basin

B. F. Alemaw and

J.-M. Kileshye-Onema

Title Page

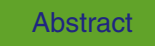

Introduction

Conclusions

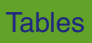

Figures

14

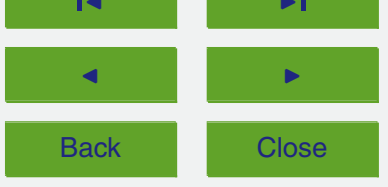

Full Screen / Esc

Printer-friendly Version

Interactive Discussion 
Sadri, S. and Burn, D. H.: A Fuzzy C-Means approach for regionalization using a bivariate homogeneity and discordancy approach, J. Hydrol., 401, 231-239, 2011.

Tallaksen, L. M.: Streamflow drought frequency analysis, in: Drought and Drought Mitigation in Europe, edited by: Vogt, J. V. and Somma, F., Kluwer Academic Publishers, Dordrecht, the Netherlands, 103-117, 2000.

Tate, E. L. and Gustard, A.: Drought definition: a hydrological perspective, In: Drought and Drought Mitigation in Europe, edited by Vogt, J. V. and Somma, F., Kluwer Academic Publishers, Dordrecht, the Netherlands, 23-48, 2000.

Werner, M., Nyabeze, W., Engelbrecht, F., Pappenberger, F., Iglesias, A., Barbosa, P., Kileshye-

\footnotetext{
Onema, J.-M.: Drought forecasting and warning in Africa: recent advances from the DEWFORA Project, 8th International Conference of EWRA, Porto, Portugal, 26-29 June, 2013.

Wilhite, D. A. and Glantz, M. H.: Understanding the drought phenomenon: the role of definitions, Water Int., 10, 111-120, 1985.

Yevjevich, V. M.: An Objective Approach to Definitions and Investigations of Continental Hydro15 logic Droughts, Hydrological Papers, Colorado State Univ., Fort Collins, 23, 1967.

Zhang, Q., Xu, C.-Y., Gemmer, M., Chen, Y. D., and Liu, C.: Changing Properties of Precipitation

Evaluation of drought regimes and impacts in the Limpopo basin

\section{B. F. Alemaw and \\ J.-M. Kileshye-Onema}

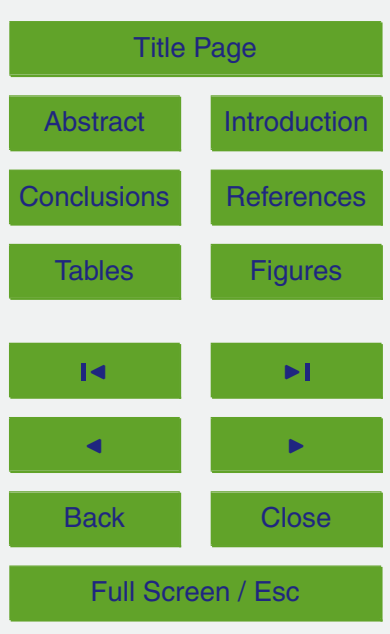

Printer-friendly Version

Interactive Discussion 


\section{HESSD}

$11,199-222,2014$

Evaluation of drought regimes and impacts

in the Limpopo basin

B. F. Alemaw and

Table 1. SPI-based drought categories and event probabilities.

\begin{tabular}{llc}
\hline Category & SPI Value & Probability (\%) \\
\hline Extremely wet & $\geq 2.00$ & 2.3 \\
Severely wet & 1.50 to 1.99 & 4.4 \\
Moderately wet & $1.00-1.49$ & 9.2 \\
Near normal & $-0.99-0.99$ & 68.2 \\
Moderate drought & -1.00 to -1.49 & 9.2 \\
Severe drought & -2.00 to -1.50 & 4.4 \\
Extreme drought & $\leq-2.00$ & 2.3 \\
\hline
\end{tabular}

J.-M. Kileshye-Onema

Title Page

Abstract

Introduction

Conclusions

References

Tables

Figures

14

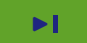

4

Back

Full Screen / Esc

Printer-friendly Version

Interactive Discussion 


\section{HESSD}

11, 199-222, 2014

Evaluation of drought regimes and impacts

in the Limpopo basin

B. F. Alemaw and

J.-M. Kileshye-Onema

Table 2. WRSI-based drought severity class.

\begin{tabular}{cl}
\hline WRSI (\%) & drought severity class \\
\hline $80-100$ & No drought \\
$70-79$ & Slight drought \\
$60-69$ & Moderate drought \\
$50-59$ & Severe drought \\
$<50-59$ & Very severe drought
\end{tabular}

Title Page

Abstract

Introduction

Conclusions

References

Tables

Figures

14

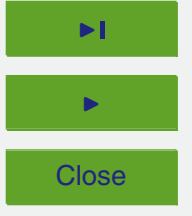

Back

Full Screen / Esc

Printer-friendly Version

Interactive Discussion 


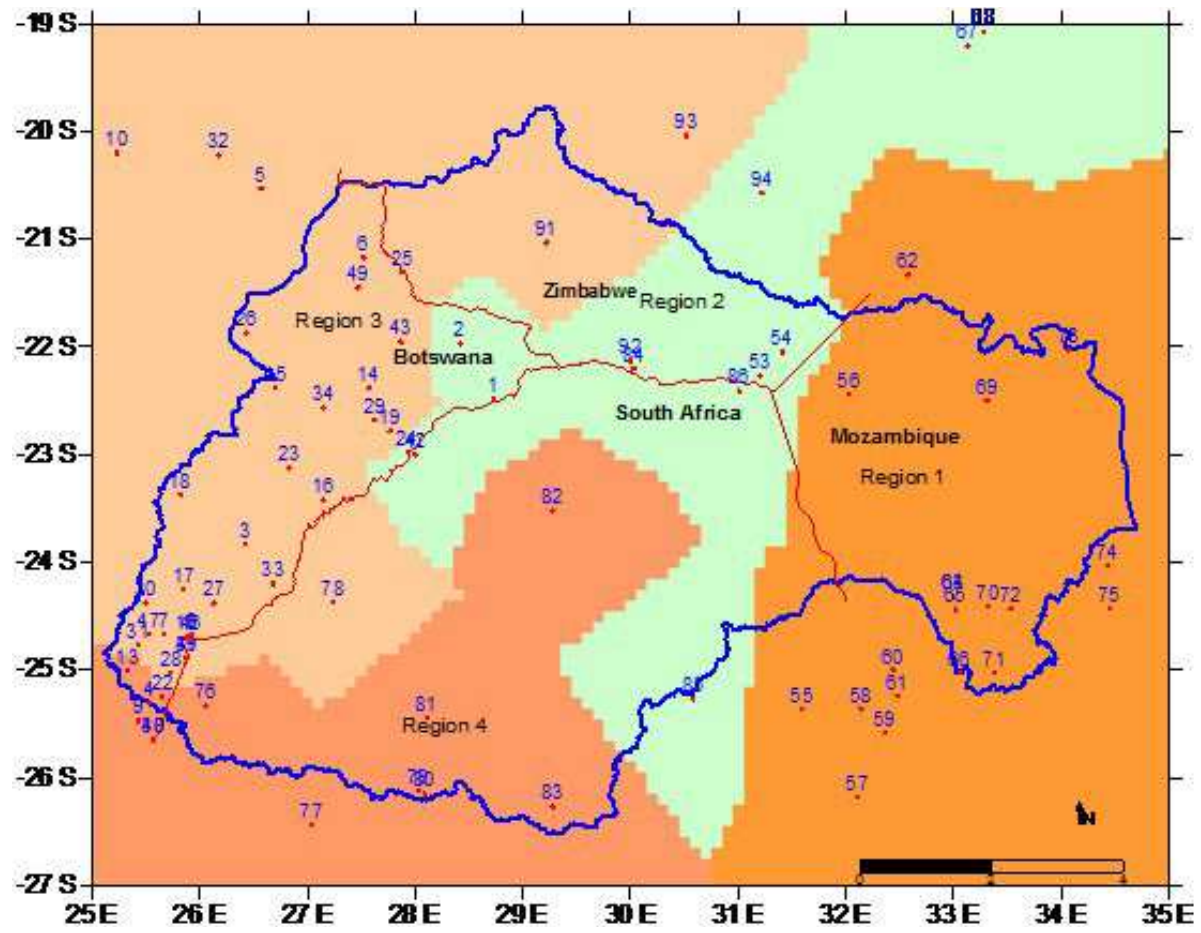

Fig. 1. Four homogenous drought regions of Botswana demarcated through clustering (from Alemaw et al., 2013).

\section{HESSD}

$11,199-222,2014$

Evaluation of drought regimes and impacts in the Limpopo basin

B. F. Alemaw and J.-M. Kileshye-Onema

Title Page

Abstract

Introduction

Conclusions

References

Tables

Figures

14

$\rightarrow 1$

Back

Close

Full Screen / Esc

Printer-friendly Version

Interactive Discussion 


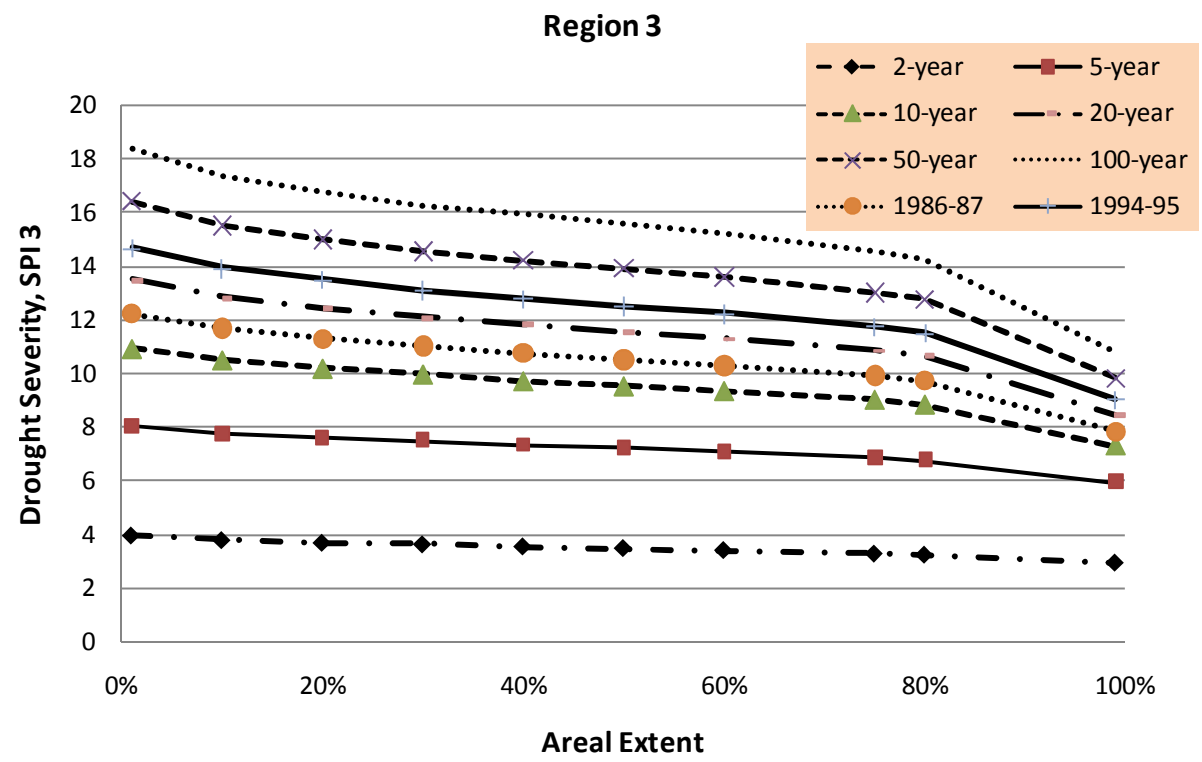

Fig. 2. Severity-Area-Frequency (SAF) curve of SPI-3 month for Region 3 of the Limpopo River basin.

\section{HESSD}

$11,199-222,2014$

Evaluation of drought regimes and impacts in the Limpopo basin

B. F. Alemaw and J.-M. Kileshye-Onema

Title Page

Abstract Introduction

Conclusions References

Tables Figures

14 $\rightarrow 1$

4

Back

Close

Full Screen / Esc

Printer-friendly Version

Interactive Discussion 


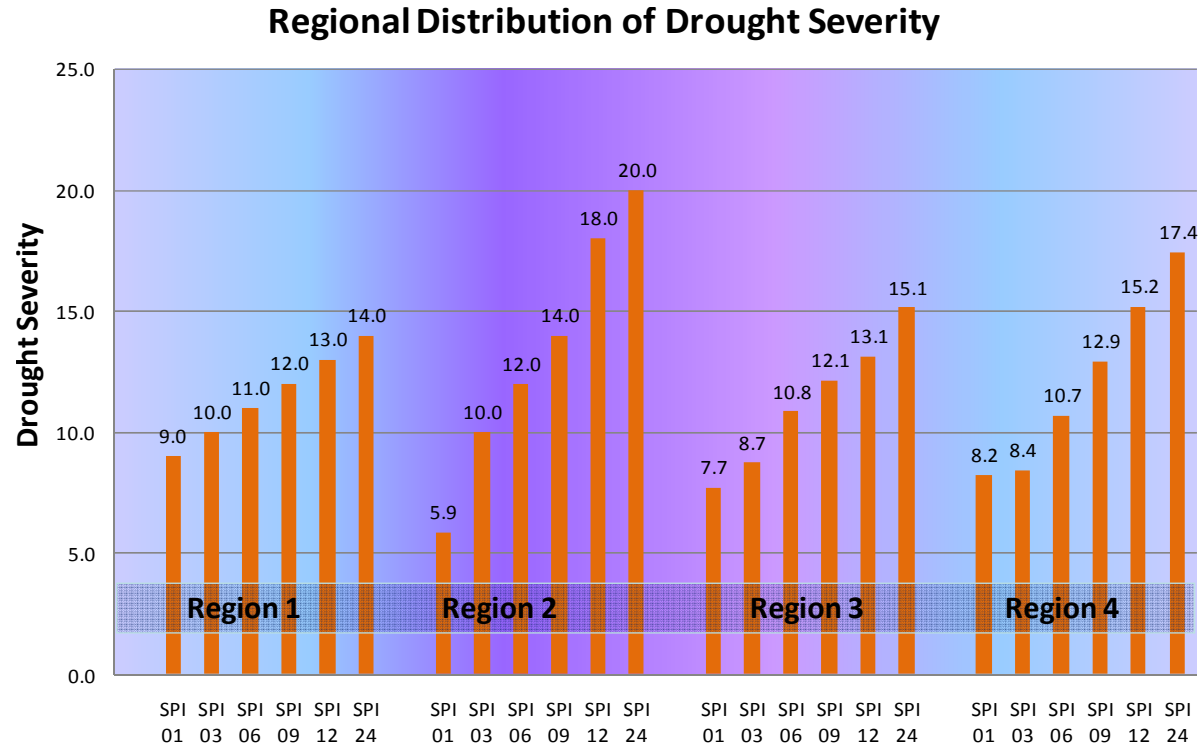

Fig. 3. Aggregated mean regional distribution of drought severity computed from running sums of multiple time scales of SPIs (from Alemaw et al., 2013).

\section{HESSD}

$11,199-222,2014$

Evaluation of drought regimes and impacts in the Limpopo basin

\section{B. F. Alemaw and J.-M. Kileshye-Onema}

\section{Title Page}

\section{Abstract}

Introduction

Conclusions

References

Tables

Figures

14

\section{Back}

\section{Close}

\section{Full Screen / Esc}

Printer-friendly Version

Interactive Discussion 


\section{HESSD}

11, 199-222, 2014

Evaluation of drought regimes and impacts in the Limpopo basin

\section{a) Palapye: Maize, $p=10 \%$}

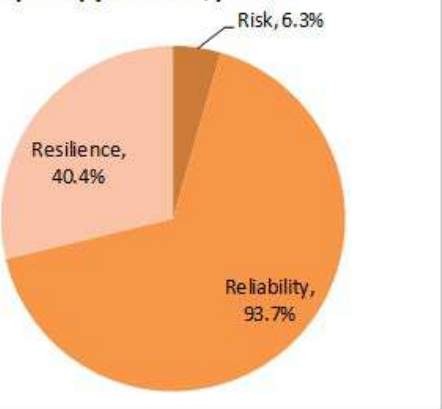

\section{b) Bobonong: Maize, $p=20 \%$}

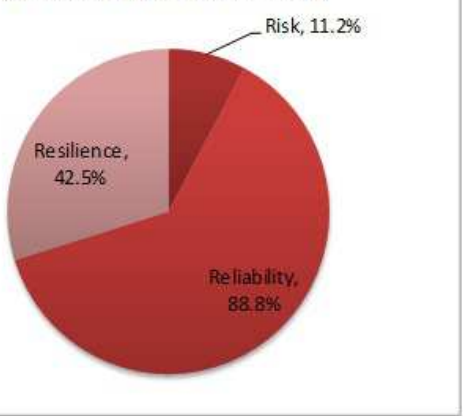

B. F. Alemaw and

J.-M. Kileshye-Onema

Title Page

Abstract

Introduction

Conclusions

References

Tables

Figures

Fig. 4. Risk, reliability and resilience of maize with available soil moisture factor, $p=10 \%$ in two districts of Region; (a) Palapye District, (b) Bobonong District.

14

4

Back

Full Screen / Esc

Printer-friendly Version

Interactive Discussion
$>1$

Close 


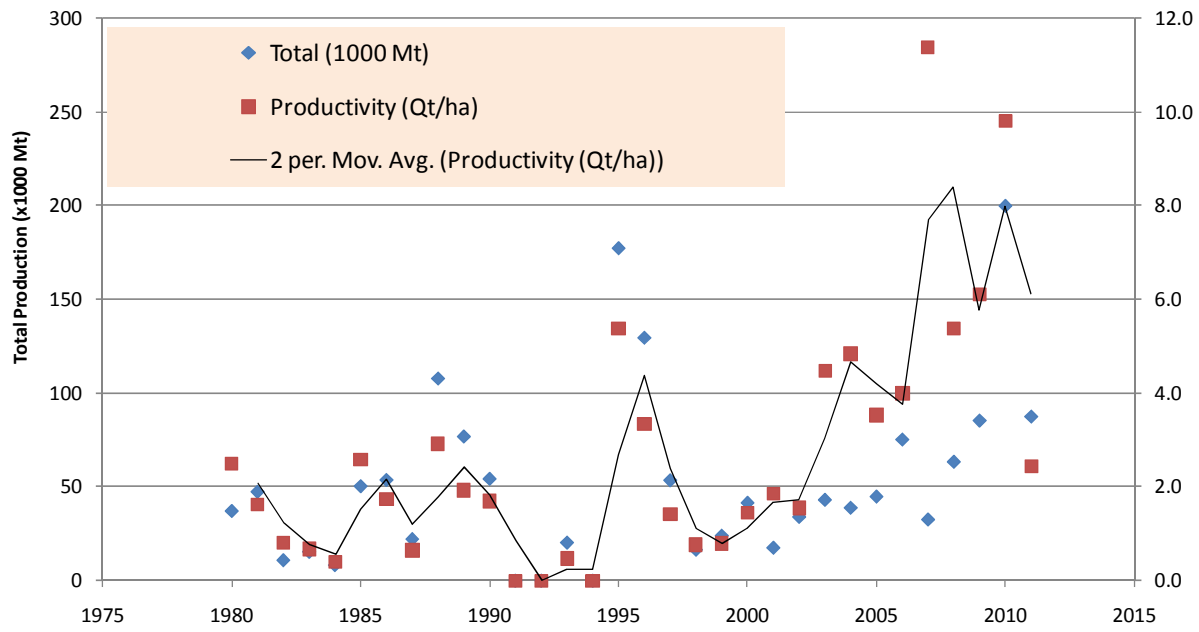

Fig. 5. Crop production and yield data (Region 3); the production in Mt is a combination rainfed crops produced namely: sorghum, maize, millet, pulses, Sunflower and Groundnuts, among others.

\section{HESSD}

$11,199-222,2014$

Evaluation of drought regimes and impacts in the Limpopo basin

B. F. Alemaw and J.-M. Kileshye-Onema

Title Page

Abstract Introduction

Conclusions References

Tables Figures

14

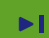

Back

Close

\section{Full Screen / Esc}

Printer-friendly Version

Interactive Discussion 